\title{
Sosialisasi Manajemen Klinis untuk Peningkatan Mutu Pelayanan Kesehatan bagi Profesional Perekam Medis
}

\author{
Rahmi Septia Sari*1, Yanti Desnita Tasri², Rindy Shakila ${ }^{3}$ \\ 1,2,3 Program Studi Ilmu Rekam Medis, Akademi Perekam dan Informasi Kesehatan. \\ *e-mail: rahmiseptiasari88@gmail.com¹,zyri_bkt@yahoo.com ${ }^{2}{ }^{\text {rindysakila14@gmail.com }}$
}

\begin{abstract}
Health facilities are very important services for the community. The most important health service is to produce beneficial outcomes for patients, users and society. Achieving this outcome is highly dependent on the quality of health services. Improving the quality of clinical services is one of the efforts to manage the quality of health services. Information about health services from all users of medical services and all individuals is needed as a source of data to answer questions about the quality of health services. So that accurate information is obtained. The purpose of this activity is to provide information and knowledge to medical recorders about the quality of health services related to clinical quality management in improving performance and implementing clinical management concepts. There are several perspectives regarding the quality of health services, including according to consumers of health services as a service that can meet the needs of the community, according to quality health service providers, namely the availability of equipment, work procedures, professional freedom in performing health services, according to funders of health services as a health service. In an effective and efficient manner, according to the owner of health care facilities, quality health services can generate income that is able to cover operational costs, while according to health service administrators, it can provide for the needs of patients and health care providers. The method used is by providing information directly through virtual media to medical recorders.
\end{abstract}

Keywords: Management, Clinical, Quality, Service, Medical Record

\begin{abstract}
Abstrak
Adapun permasalahan yang diungkap dalam fasilitas kesehatan adalah yang terkait dengan sumber daya manusia yang berkualitas sehingga nantinya mempengaruhi kinerja dan mutu pelayanan kesehatan. Fasilitas kesehatan merupakan pelayanan yang sangat penting bagi masyaraka. Pelayanan kesehatan yang paling utama adalah menghasilkan outcome yang menguntungkan bagi pasien, pengguna dan masyarakat. Pencapaian outcome ini sangat tergantung pada mutu pelayanan kesehatan. Peningkatan mutu pelayanan klinis merupakan salah satu upaya manajemen mutu pelayanan kesehatan. Informasi mengenai pelayanan kesehatan dari seluruh pengguna jasa pelayanan medis maupun seluruh individu diperlukan sebagai sumber data untuk menjawab pertanyaan mengenai mutu pelayanan kesehatan. Sehingga diperoleh informasi yang akurat. Tujuan kegiatan adalah untuk memberikan informasi dan pengetahuan kepada para perekam medis tentang mutu pelayanan kesehatan terkait manajemen mutu klinis dalam peningkatan kinerja serta mengimplementasikan konsep manajemen klinis. Terdapat beberapa perspektif mengenai mutu pelayanan kesehatan diantaranya menurut konsumen layanan kesehatan sebagai suatu layanan yang dapat memenuhi kebutuhan masyarakat, menurut provider layanan kesehatan yang bermutu yaitu tersedianya peralatan, prosedur kerja, kebebasan profesi dalam melakukan layanan kesehatan, menurut penyandang dana layanan kesehatan sebagai suatu layanan kesehatan yang efektif dan efisien, menurut pemilik sarana layanan kesehatan bahwa layanan kesehatan yang bermutu dapat menghasilkan pendapatan yang mampu menutupi biaya operasional sedangkan menurut administrator layanan kesehatan dapat menyediakan kebutuhan pasien serta pemberi layanan kesehatan. Adapun metode yang dilakukan adalah dengan cara memberikan informasi langsung melalui media virtual kepada perekam medis.
\end{abstract}

Kata kunci: Manajemen, Klinis, Mutu, Pelayanan, Perekam Medis 
ABDINE: Jurnal Pengabdian Kepada Masyarakat Vol.1, No.2, Desember 2021, Hal. 147-158 p-ISSN 2798-2882, e-ISSN 2798-2890

\section{PENDAHULUAN}

Pelayanan kesehatan ialah setiap upaya yang diselenggarakan sendiri atau secara bersama-sama dalam suatu organisasi untuk memelihara dan meningkatkan kesehatan, mencegah dan menyembuhkan penyakit serta memulihkan kesehatan perseorangan keluarga, kelompok, dan ataupun masyarakat. Pelayanan kesehatan menurut Permenkes No.4 tahun 2019 tentang kesehatan ialah setiap upaya yang diselenggarakan sendiri atau secara bersama-sama dalam suatu organisasi untuk memelihara dan meningkatkan kesehatan, mencegah dan menyembuhkan penyakit serta memulihkan kesehatan, perorangan, keluarga, kelompok ataupun masyarakat.

Adapun menurut penjelasan Sugiharti, dkk (2019) Pelayanan kesehatan adalah setiap upaya yang diselenggarakan sendiri atau secara bersama-sama dalam suatu organisasi seperti puskesmas untuk memelihara dan meningkatkan kesehatan, mencegah dan menyembuhkan penyakit serta memulihkan perseorangan, keluarga kelompok, dan ataupun masyarakat. Peningkatan mutu kesehatan harus selalu dilaksanakan dengan berbagai macam metode terkini, salah satunya dengan memberikan pengetahuan menggunakan teknologi informasi (Elisa Hafida, Febrina Sari, Desyanti 2020)

Salah satu syarat pokok pelayanan kesehatan adalah bermutu, yaitu menunjuk pada tingkat kesempurnaan pelayanan kesehatan yang diselenggarakan, yang disatu pihak dapat memuaskan para pemakai jasa pelayanan, dan di pihak lain tata cara penyelenggaraannya sesuai dengan kode etik serta standar yang telah di tetapkan.

Untuk mewujudkan hal tersebut maka mutu pelayanan harus dapat terukur, terpantau dan termonitor. Pengukuran merupakan konsep sentral dalam peningkatan mutu. Dengan pengukuran akan tergambarkan apa yang sebenarnya sedang dilakukan sarana pelayanan kesehatan dan membandingkannya dengan target sesungguhnya atau harapan tertentu dengan tujuan untuk mengidentifikasi kesempatan untuk adanya peningkatan mutu. Untuk mengukur suatu pelayanan kesehatan diperlukan suatu petunjuk atau tolak ukur, tolak ukur / petunjuk tersebut dinamakan indikator. Indikator adalah petunjuk atau tolak ukur/Indikator adalah fenomena yang dapat diukur. Contoh indikator atau tolak ukur status kesehatan antara lain adalah angka kematian ibu, angka kematian bayi, status gizi.

Menjaga mutu (Quality Assurance) sering diartikan sebagai menjamin mutu atau memastikan mutu. Seperti pada penggunaan kata to assure (=to convince, to make sure or certain, to ensure, to secure) artinya adalah meyakinkan orang, mengusahakan sebaik- baiknya, mengamankan atau menjaga.

Dalam hal ini manajemen mutu merupakan tanggapan umum dari institusi pelayanan kesehatan terhadap ancaman dari lingkungan luar. Pemberian pelayanan kesehatan harus mencerminkan ketepatan dari penggunaan pengetahuan terbaru secara ilmiah, klinis, teknis, interpersonal, manual, kognitif, organisasi serta unsurunsur manajemen pelayanan kesehatan. Di rumah sakit maupun pelayanan kesehatan lain dikenal beberapa sumber data utama yang terdiri dari berkas administrasi, hasil pendataan pasien dan rekam medis pasien. Dengan manajemen informasi sumber data tersebut dapat terpadu dalam satu sistem yang dapat di analisis dan di evaluasi guna perbaikan mutu informasi kesehatan serta pelayanan kesehatan pada umumnya.

\section{A. Perspektif Mutu Pelayanan Kesehatan}

Setiap mereka yang terlibat dalam layanan kesehatan seperti pasien, masyarakat dan organisasi masyarakat, profesi layanan kesehatan, dinas kesehatan, dan pemerintah daerah, pasti mempunyai persepsi yang berbeda tentang unsur penting dalam menentukan mutu layanan kesehatan. Perbedaan ini antara lain disebabkan 
ABDINE: Jurnal Pengabdian Kepada Masyarakat Vol.1, No.2, Desember 2021, Hal. 147-158 p-ISSN 2798-2882, e-ISSN 2798-2890

oleh terdapatnya perbedaan latar belakang, pendidikan, pengetahuan, pekerjaan, pengalaman, lingkungan dan kepentingan

Menurut (Azwar, 2013) (Bustami, 2016) (Elisabeth \& Elisabeth, 2015) (Herlambang, 2016) (A A Gde, 2013) (Sabarguna, 2014) (Spath, 2014) (RI, 2019) (Prastiwi, 2010) (D, 2012)Wijono (2012), beberapa perspektif mengenai mutu pelayanan kesehatan yaitu:

1. Bagi pemakai jasa pelayanan kesehatan/masyarakat

Pasien/masyarakat (konsumen) melihat layanan kesehatan yang bermutu sebagai suatu layanan kesehatan yang dapat memenuhi kebutuhan dan diselenggarakan dengan cara yang sopan dan santun, tepat waktu, tanggap dan mampu menyembuhkan keluhannya serta mencegah berkembangnya atau meluas penyakitnya. Pandangan pasien ini sangat penting karena pasien yang merasa puas akan mematuhi pengobatan dan mau datang berobat kembali. Pemberi layanan harus memahami status kesehatan dan kebutuhan layanan kesehatan masyarakat yang dilayaninya dan mendidik masyarakat tentang layanan kesehatan dasar dan melibatkan masyarakat dalam menentukan bagaimana cara yang paling efektif menyelenggarakan layanan kesehatan, sehingga diperlukan suatu hubungan yang saling percaya antara pemberi layanan kesehatan atau provider dengan pasien/masyarakat.

2. Bagi pemberi layanan kesehatan

Pemberi layanan kesehatan (provider) mengaitkan layanan kesehatan yang bermutu dengan ketersediaan peralatan, prosedur kerja atau protokol, kebebasan profesi dalam melakukan setiap layanan kesehatan sesuai dengan teknologi kesehatan mutakhir, dan bagaimana keluaran (outcome) atau hasil layanan kesehatan tersebut.Komitmen dan motivasi pemberi layanan kesehatan bergantung pada kemampuannya dalam melaksanakan tugas dengan cara yang optimal. Profesi layanan kesehatan membutuhkan dan mengaharapkan adanya dukungan teknis, administratif, dan layanan pendukung lainnya yang efektif serta efisien dalam menyelenggarakan layanan kesehatan yang bermutu tinggi.

3. Bagi penyandang dana pelayanan kesehatan

Penyandang dana atau asuransi kesehatan menganggap bahwa layanan kesehatan yang bermutu sebagai suatu layanan kesehatan yang efektif dan efisien. Pasien diharapkan dapat disembuhkan dalam waktu yang sesingkat mungkin sehingga biaya pengobatan dapat menjadi efisien. Kemudian upaya promosi kesehatan dan pencegahan penyakit akan ditingkatkan agar layanan kesehatan penyembuhan semakin berkurang.

4. Bagi pemilik sarana layanan kesehatan

Pemilik sarana layanan kesehatan berpandangan bahwa layanan kesehatan yang bermutu merupakan layanan kesehatan yang menghasilkan pendapatan yang mampu menutupi biaya operasional dan pemeliharaan, tetapi dengan tarif yang masih terjangkau oleh pasien/masyarakat, yaitu pada tingkat biaya yang tidak mendapat keluhan dari pasien dan masyarakat.

5. Bagi administrator layanan kesehatan

Administrator walau tidak langsung memberikan layanan kesehatan pada masyarakat, ikut bertanggung jawab dalam masalah mutu layanan kesehatan. Administrator dapat menyusun prioritas dalam menyediakan apa yang menjadi kebutuhan dan harapan pasien serta pemberi layanan kesehatan.

\section{B. Standar Mutu Pelayanan Kesehatan}

Untuk menjaga pelaksanaan program pelayanan kesehatan agar tetap berpedoman kepada standar yang telah ditetapkan maka disusunlah pedoman petunjuk pelaksanaan, yaitu penyataan tertulis yang disusun secara sistematis dan yang dipakai 
ABDINE: Jurnal Pengabdian Kepada Masyarakat Vol.1, No.2, Desember 2021, Hal. 147-158 p-ISSN 2798-2882, e-ISSN 2798-2890

sebagai pedoman oleh pelaksanaan dalam mengambil keputusan dan atau dalam melaksanakan pelayanan kesehatan.

Untuk mengukur tercapai atau tidaknya standar yang telah ditetapkan maka dipergunakan indikator, yaitu ukuran kepatuhan terhadap standar yang telah ditetapkan. Semakin sesuai suatu yang diukur dengan indikator, semakin sesuai keadaanya dengan standar yang telah ditetapkan.

Menurut Herlambang (2016), sesuai dengan peranan yang dimiliki oleh masingmasing unsur pelayanan kesehatan, standar dalam program menjaga mutu secara umum dapat dibedakan menjadi dua macam yaitu:

1. Standar Persyaratan Minimal

Standar persyaratan minimal adalah yang menunjuk kepada keadaan minimal yang harus dipenuhi untuk dapat menjamin terselenggaranya pelayanan kesehatan bermutu.

a. Standar Masukan

Dalam standar masukan ditetapkan persyaratan minimal unsur masukan yang diperlukan untuk dapat menyelenggarakan pelayanan kesehatan yang bermutu, yaitu jenis, jumlah, dan kualifikasi tenaga pelaksana, jenis, jumlah dan spesifikasi pada tenaga pelaksana, serta jumlah dana (standar tenaga, standar sarana)

b. Standar Lingkungan

Dalam standar lingkungan ditetapkan persyaratan minimal unsur lingkungan yang diperlukan untuk dapat menyelenggarakan pelayanan kesehatan yang bermutu, yaitu garis-garis besar kebijakan, pola organisasi serta sistem manajemen yang harus dipenuhi oleh setiap pelaksana pelayanan (standar organisasi dan manajemen)

c. Standar Proses

Dalam standar proses ditetapkan persyaratan minimal unsur proses yang harus dilakukan untuk dapat menyelenggaran pelayanan kesehatan yang bermutu yaitu tindakan medis dan tindakan nonmedis pelayanan kesehatan (standar tindakan)

2. Standar Penampilan Minimal

Standar penampilan minimal adalah yang menunjuk kepada penampilan pelayanan kesehatan yang masih dapat diterima. Standar ini, karena menunjuk kepada unsur keluaran, disebut dengan nama standar keluaran atau standar penampilan. Untuk dapat meningkatkan mutu pelayanan kesehatan keempat standar ini perlulah dipantau serta dinilai secara obyektif dan berkesinambungan. Apabila ditemukan penyimpangan, perlu segera diperbaiki. Pemantauan dan penilaian standar ini diukur dari indikator yang sesuai, yang secara umum dapat dibedakan menjadi empat macam, yaitu indikator masukan, indikator proses, indikator lingkungan, serta indikator keluaran.

Menurut Azwar dalam Herlambang (2016), menyatakan bahwa syarat pokok dalam memberikan pelayanan kesehatan yang bermutu adalah:

1. Tersedia dan berkesinambungan

Syarat pokok pertama pelayanan kesehatan yang baik adalah pelayanan tersebut harus tersedia di masyarakat (available) serta bersifat berkesinambungan (continuous). Artinya semua jenis pelayanan kesehatan yang dibutuhkan oleh masyarakat dan mudah dicapai oleh masyarakat.

2. Dapat diterima dan wajar

Syarat pokok kedua pelayanan kesehatan yang baik adalah apa yang dapat diterima (acceptable) oleh masyarakat serta bersifat wajar (appropriate). Artinya pelayanan kesehatan tersebut tidak bertentangan dengan adat istiadat, kebudayaan, keyakinan, kepercayaan masyarakat dan bersifat wajar.

3. Mudah dicapai 
ABDINE: Jurnal Pengabdian Kepada Masyarakat Vol.1, No.2, Desember 2021, Hal. 147-158 p-ISSN 2798-2882, e-ISSN 2798-2890

Syarat pokok ketiga pelayanan kesehatan yang baik adalah yang mudah dicapai (accessible) oleh masyarakat. Pengertian ketercapaian yang dimaksud disini terutama dalam sudut lokasi. Dengan demikian untuk mewujudkan pelayanan kesehatan yang baik, maka pengaturan sarana kesehatan menjadi sangat penting.

4. Mudah dijangkau

Syarat pokok pelayanan kesehatan yang keempat adalah mudah dijangkau (affordable) oleh masyarakat. Pengertian keterjangkauan disini terutama dari sudut jarak dan biaya. Untuk mewujudkan keadaan seperti ini harus diupayakan pendekatan sarana pelayanan kesehatan dan biaya kesehatan diharapkan sesuai dengan kemampuan ekonomi masyarakat.

5. Bermutu

Syarat pokok pelayanan kesehatan yang kelima adalah yang bermutu (quality). Pengertian mutu yang dimaksud adalah yang menunjuk pada tingkat kesempurnaan pelayanan kesehatan yang diselenggarakan, yang disatu pihak dapat memuaskan para pemakai jasa pelayanan, dan pihak lain tata cara penyelenggaraannya sesuai dengan kode etik serta standar yang telah ditetapkan.

\section{Mengukur Mutu Pelayanan Kesehatan}

Menurut pohan dalam Prastiwi (2010), langkah pengukuran mutu tersebut dapat dipilah-pilah menjadi beberapa langkah sebagai berikut:

1. Pembentukan kelompok jaminan mutu pelayanan kesehatan

2. Penyusunan standar pelayanan kesehatan

3. Pemilihan tehnik pengukuran mutu

4. Pengukuran mutu dengan cara membandingkan standar pelayanan kesehatan dengan kenyataan yang tercapai.

Donabedian dalam Prastiwi (2010), menganjurkan agar standar dan kriteria diklasifikasikan kedalam tiga kelompok, hal ini pada prinsipnya sama dengan yang dianjurkan oleh World Health Organitation (WHO) yaitu:

\section{Standar struktur/input}

Standar struktur atau masukan menentukan tingkat sumber daya yang diperlukan agar standar pelayanan kesehatan dapat dicapai. Contohnya antara lain ialah: personel, pasien, peralatan, bahan gedung, pencatatan, keuangan, singkatnya semua sumber daya yang digunakan untuk dapat melakukan pelayanan kesehatan seperti yang tersebut dalam standar pelayanan kesehatan.

Standar struktur antara lain ialah tenaga kesehatan yang kompeten, peralatan pemeriksaan, obat, kamar pemeriksaan, pasien dan waktu konsultasi harus ditentukan.

2. Standar proses/process

Standar proses menentukan kegiatan apa yang harus dilakukan agar standar pelayanan kesehatan dapat dicapai, proses akan menjelaskan apa yang dikerjakan, untuk siapa, siapa yang mengerjakan, kapan dan bagaimana standar pelayanan kesehatan dapat dicapai.

Dalam contoh standar pelayanan ISPA, maka sebagai proses adalah, petugas kesehatan memeriksa balita yang batuk, dengan melakukan anamnesis dan pemeriksaan fisik seperti apa yang telah ditentukan dalam standar pelayanan kesehatan. Semua hasil anamnesis dan pemeriksaan fisik tersebut dicatat dengan lengkap dan akurat dalam rekam medik.

3. Standar keluaran atau output 
ABDINE: Jurnal Pengabdian Kepada Masyarakat Vol.1, No.2, Desember 2021, Hal. 147-158 p-ISSN 2798-2882, e-ISSN 2798-2890

Standar keluaran atau output atau hasil pelayanan kesehatan ialah hasil pelayanan kesehatan yang dilaksanakan sesuai standar pelayanan kesehatan dan ini sangat penting. Kriteria 'outcome' yang umum digunakan antara lain:

a. Kepuasan pasien

b. Pengetahuan pasien

c. Fungsi pasien

d. Indikator kesembuhan, kematian, komplikasi dll.

Salah satu pengukuran mutu pelayanan kesehatan dengan membandingkan terhadap standar pelayanan kesehatan yang telah ditetapkan. Pengertian standar pelayanan kesehatan ialah suatu pernyataan tentang mutu yang diharapkan, yang menyangkut input/masukan, proses dan keluaran/output. Standar pelayanan kesehatan merupakan suatu alat organisasi untuk menjabarkan mutu kedalam terminologi operasional. Standar, indikator dan nilai ambang batas merupakan unsur-unsur yang akan membuat jaminan mutu pelayanan kesehatan dapat diukur. Indikator didefinisikan sebagai tolok ukur untuk mengetahui adanya perubahan yang dikaitkan dengan target/standar yang telah ditentukan sebelumnya. Jenis-jenis indikator bisa dikelompokkan berdasarkan; Input (berkaitan dengan man, money, material, method dan management), process (berkaitan dengan proses yang dilakukan untuk menghasilkan sesuatu baik barang maupun jasa), output (berkaitan dengan sesuatu yang dihasilkan bisa dalam bentuk barang ataupun selesainya pekerjaan jasa), outcome (berkaitan dengan ukuran yang dirasakan pelanggan, biasanya merupakan persepsi pelanggan terhadap pemanfaatan layanan), benefit (berkaitan dengan ukuran terhadap manfaat bagi pelanggan atau bagi pemberi pelayanan) dan impact (berkaitan dengan ukuran dampak dari suatu produk secara luas dan biasanya jangka panjang).

Dalam Prastiwi (2010), diungkapkan bahwa pengukuran mutu pelayanan kesehatan dapat dilakukan melalui tiga cara, yaitu:

1. Pengukuran mutu prospektif

Pengukuran mutu prospektif yaitu pengukuran mutu pelayanan kesehatan yang dilakukan sebelum pelayanan kesehatan diselengarakan. Oleh sebab itu, pengukurannya ditujukan terhadap struktur atau masukan pelayanan kesehatan dengan asumsi bahwa pelayanan kesehatan harus memiliki sumber daya tertentu agar dapat menghasilkan pelayanan kesehatan yang bermutu, seperti:

a. Pendidikan profesi kesehatan

Pendidikan profesi pelayanan kesehatan ditujukan agar menghasilkan profesi pelayanan kesehatan yang mempunyai pengetahuan, keterampilan dan perilaku yang dapat mendukung pelayanan kesehatan yang bermutu.

b. Perizinan atau 'Licensure'

Perizinan merupakan salah satu mekanisme untuk menjamin mutu pelayanan kesehatan. SID (Surat Izin Dokter) dan SIP (Surat Izin Praktek) yang diberikan merupakan suatu pengakuan bahwa dokter tersebut memenuhi syarat untuk melakukan profesi dokter. Demikian pula halnya degan profesi kesehatan lain, harus mempunyai izin kerja sesuai dengan profesinya. Mekanisme perizinan belum menjamin sepenuhnya kompetensi tenaga kesehatan yang ada atau mutu pelayanan kesehatan fasilitas pelayanan kesehatan tersebut.

c. Standardisasi

Dengan menerapkan standardisasi, seperti standardisasi peralatan, tenaga, gedung, sistem, organisasi, anggaran, dll, maka diharapkan fasilitas pelayanan kesehatan menjadi bermutu. Standardisasi akan membangun klasifikasi pelayanan kesehatan. Contohnya standardisasi pelayanan rumah sakit akan dapat mengelompokkan atau mengklasifikasikan rumah sakit 
dalam berbagai kelas tertentu, misalnya rumah sakit umum kelas A, kelas B, kelas C dan kelas D. Rumah sakit jiwa kelas A dan kelas B.

d. Sertifikasi (certification)

Sertifikasi adalah langkah selanjutnya dari perizinan. Misalnya, pengakuan sebagai dokter spesialis adalah sertifikasi. Di Indonesia perizinan itu dilakukan oleh departemen kesehatan atau dinas kesehatan sedang sertifikasi oleh pendidikan profesi (Dpdikbud, CHS, Organisasi Profesi).

e. Akreditasi

Akreditasi adalah pengakuan bahwa suatu instuisi pelayanan kesehatan seperti rumah sakit telah memenuhi beberapa standar pelayanan kesehatan tertentu. Indonesia telah melakukan akreditasi rumah sakit umum yang dilakukan oleh Departemen Kesehatan.

Pengukuran mutu prospektif terfokus pada penilaian sumber daya, bukan kinerja penyelenggaraan pelayanan kesehatan. Ini merupakan salah satu kekurangan pengukuran mutu dengan cara prospektif (Prastiwi, 2010).

2. Pengukuran mutu konkuren

Pengukuran mutu konkuren yaitu pengukuran pengukuran mutu pelayanan kesehatan yang dilakukan selama pelayanan kesehatan sedang berlangsung, yaitu dengan melakukan pengamatan langsung dan kadang-kadang perlu dilengkapi dengan melihat rekam medik, wawancara dengan pasien/keluarga/petugas kesehatan, dan melakukan pertemuan dengan pasien/keluarga/petugas kesehatan.

3. Pengukuran mutu retrospektif

Pengukuran mutu retrospektif yaitu pengukuran mutu pelayanan kesehatan yang dilakukan sesudah pelayanan kesehatan selesai dilaksanakan dan biasanya merupakan gabungan beberapa kegiatan yang berikut:

a. Menilai rekam medik

Memeriksa dan kemudian menilai catatan rekam medik atau catatan lain dan kegiatan ini disebut sebagai audit.

b. Wawancara

Wawancara dengan pasien dan keluarga/teman/petugas kesehatan.

c. Membuat Kuisioner

Membuat kuisioner yang dibagikan kepada pasien dan keluarga/teman/petugas kesehatan.

d. Melakukan pertemuan

Melakukan pertemuan dengan pasien dan petugas kesehatan terkait.

\section{Manfaat Program Jaminan Mutu Kesehatan}

Program menjaga mutu adalah suatu upaya yang dilakukan secara berkesinambungan, sistematis, objektif dan terpadu dalam menetapkan masalah dan penyebab masalah mutu pelayanan kesehatan berdasarkan standar yang telah ditetapkan, menetapkan dan melaksanakan cara penyelesaian masalah sesuai dengan kemampuan yang tersedia, serta menilai hasil yang dicapai dan menyusun saran-saran tindak lanjut untuk lebih meningkatkan mutu pelayanan kesehatan.

Menurut Herlambang (2016), menyatakan bahwa manfaat dari program jaminan mutu adalah:

1. Dapat Meningkatkan Efektifitas Pelayanan Kesehatan

Peningkatan efektifitas pelayanan kesehatan ini erat hubungannya dengan dapat diatasinya masalah kesehatan secara tepat, karena pelayanan kesehatan yang diselenggarakan telah sesuai dengan kemajuan ilmu dan teknologi ataupun standar yang telah ditetapkan.

2. Dapat Meningkatkan Efisiensi Pelayanan Kesehatan 
ABDINE: Jurnal Pengabdian Kepada Masyarakat Vol.1, No.2, Desember 2021, Hal. 147-158 p-ISSN 2798-2882, e-ISSN 2798-2890

Peningkatan efisiensi yang dimaksudkan ini erat hubungannya dengan dapat dicegahnya pelayanan kesehatan yang dibawah standar ataupun yang berlebihan. Biaya tambahan karena harus menangani efek samping atau komplikasi karena pelayanan kesehatan dibawah standar dapat dihindari. Demikian pula halnya mutu pemakaian sumber daya yang tidak pada tempatnya yang ditemukan pada pelayanan yang berlebihan.

3. Dapat Meningkatkan Penerimaan Masyarakat Terhadap Pelayanan Kesehatan Peningkatan penerimaan ini erat hubungannya dengan telah sesuainya pelayanan kesehatan dengan kebutuhan dan tuntutan pemakai jasa pelayanan. Apabila peningkatan penerimaan ini dapat diwujudkan, pada gilirannya pasti akan berperan besar dalam meningkatkan derajat kesehatan masyarakat secara keseluruhan.

4. Dapat Melindungi Penyelenggara Pelayanan Kesehatan dan Kemungkinan Timbulnya Gugatan Hukum

Pada saat ini sebagai akibat makin baiknya tingkat pendidikan masyarakat, maka kesadaran hukum masyarakat juga telah semakin meningkat. Untuk mencegah kemungkinan gugatan hukum terhadap penyelenggara pelayanan kesehatan, antara lain karena ketidakpuasan terhadap pelayanan kesehatan, perlulah diselenggarakan pelayanan kesehatan yang sebaik-baiknya.

\section{METODE}

Metode dalam pelaksanaan kegiatan ini berupa Sosialisasi secara Daring melalui ruang Zoom Meeting yang dipersiapkan tim PKM dengan peserta dari Professional Perekam Medis yang dihadiri lebih kurang 51 Peserta yang tergabung dari mitra rumah sakit seperti RSUD Kayu Aro Kabupaten Solok, RSU. M. Natsir Kota Solok, RSUD Rasidin Padang. Adapun tahapan kegiatan yang dilakukan antara lain:

1. Kegiatan Sosialisasi dibuka oleh panitia melalui ruang Zoom Meeting

2. Setelah Peserta hadir seluruhnya,kegiatan dibuka oleh moderator dan membacakan tata tertib pada kegiatan sosialisasi tentang Manajemen klinis untuk penjagaan dan peningkatan mutu pelayanan kesehatan bagi calon professional kesehatan bidang rekam medis

3. Moderator memberikan instruksi atau waktu untuk narasumber menyampaikan materi sosialisasi melalui slide power point

4. Panitia mempersilahkan peserta untuk mengisi absen mealui halaman chat yang telah di sediakan dalam bentuk absen.( https://bit.ly/AbsenPKMmandiri)

5. Setelah penjelasan mengenai materi yang disosialisasikan, peserta dipersilahkan memberikan komentar, berupa saran atau pendapat mengenai materi yang disampaikan narasumber, setelah itu dipersilahkan untuk bertanya

6. Pertanyaan yang diberikan peserta akan dijawab dan didiskusikan dengan peserta mengenai kejelasan materi yang disampaikan narasumber.

7. Semua permasalahan mengenai materi yang disosialisasi dituntaskan sampai peserta paham dengan harapan nantinya peserta dapat mengaplikasikan ilmu yang diperoleh pada saat berada dilapangan (fasilitas Kesehatan)

8. Setelah semua pertanyaan dan diskusi tuntas untuk diselesaikan, moderator menutup kegitan sosialisasi.dan mengucapkan terimakasih.

\section{HASIL DAN PEMBAHASAN}

Dari hasil sosialisasi yang dilakukan secara online terlihat Mutu pelayanan kesehatan sangat mempengaruhi derajat kesempurnaan pelayanan dan akan berpengaruh terhadap pelayanan kesehatan yang sesuai dengan standar profesi dan 
standar pelayanan dengan menggunakan potensi sumber daya yang tersedia di rumah sakit atau puskesmas secara wajar, efisien dan efektif serta diberikan secara aman dan memuaskan norma, etika, hukum, dan sosial budaya dengan memperhatikan keterbatasan dan kemampuan pemerintah dan masyarakat sebagai konsumen kesehatan. Hal ini terlihat dari komentar yang dikemukakan peserta saat berdiskusi dalam menyampaikan bagimana keadaaan yang terjadi ditempat mereka bekerja.

Dengan adanya Mutu pelayanan kesehatan dapat terpenuhinya derajat kebutuhan masyarakat atau perorangan terhadap asuhan kesehatan yang sesuai dengan standar profesi yang baik dengan pemanfaatan sumber daya secara wajar, efisien, efekif dalam keterbatasan kemampuan pemerintah dan masyarakat, serta diselenggarakan secara aman dan memuaskan pelanggan sesuai dengan norma dan etika yang baik.

Mutu pelayanan kesehatan memenuhi dan melebihi kebutuhan dan harapan pelanggan melalui peningkatan yang berkelanjutan atas seluruh proses. Pelanggan meliputi pasien, keluarga, dan lainnya yang datang untuk mendapatkan pelayanan atau lainnya. Dokter, karyawan, dan anggota masyarakat lainnya yang kita layani.

Mutu Pelayanan Kesehatan yang meliputi kinerja yang menunjukkan tingkat kesempurnaan pelayanan kesehatan, tidak saja yang dapat menimbulkan kepuasan bagi pasien sesuai dengan kepuasan rata-rata penduduk tetapi juga sesuai dengan standar dan kode etik profesi yang telah ditetapkan.

Komponen pelayanan yang terlihat dilapangan sesuai dengan pendapat dari beberapa peserta sosialisasi, terdiri dari masukan (input, disebut juga structure), proses, dan hasil (outcome).

1. Masukan (Input)

Masukan (Input) yang dimaksud disini adalah sarana fisik, perlengkapan dan peralatan, organisasi dan manajemen, keuangan, serta sumber daya manusia dan sumber daya (resources) lainnya di puskesmas dan rumah sakit. Beberapa aspek penting yang harus mendapat perhatian dalam hal ini adalah kejujuran, efektifitas dan efisiensi, serta kuantitas dan kualitas dari masukan yang ada.

Pelayanan kesehatan yang bermutu memerlukan dukungan input yang bermutu pula. Semua sumber daya yang ada perlu diorganisasikan dan dikelola sesui dengan ketentuan peraturan perundang-undangan dan prosedur kerja yang berlaku dengan maksud pelayanan kesehatan tersebut dapat diterima oleh pelanggan secara baik.

2. Proses yang dilakukan

Proses adalah semua kegiatan atau aktvitas dari seluruh karyawan dan tenaga profesi dalam interaksinya dengan pelanggan, baik pelanggan internal (sesama petugas atau karyawan) maupun pelanggan eksternal (pasien, pemasok barang, masyarakat yang datang ke puskesmas atau rumah sakit untuk maksud tertentu). Baik atau tidaknya proses yang dilakukan di puskesmas atau di rumah sakit dapat diukur dari:

a. Relevan atau tidaknya proses yang diterima oleh pelanggan

b. Efektif atau tidaknya proses yang dilakukan

c. Mutu proses yang dilakukan.

Variabel proses merupakan pendekatan langsung terhadap mutu pelayanan kesehatan. Semakin patuh petugas (profesi) terhadap standar pelayanan, maka semakin bermutu pula pelayanan kesehatan yang diberikan.

3. Hasil yang Dicapai

Hasil (outcome) yang dimaksud di sini adalah tindak lanjut dari keluaran berupa hasil akhir kegiatan dan tindakan tenaga profesi serta seluruh karyawan terhadap pelanggan. Hasil yang diharapkan dapat berupa perubahan yang terjadi pada pelanggan, baik secara fisik-fisiologis maupun sosial-psikologis, 
ABDINE: Jurnal Pengabdian Kepada Masyarakat Vol.1, No.2, Desember 2021, Hal. 147-158 p-ISSN 2798-2882, e-ISSN 2798-2890

termasuk kepuasan pelanggan. Hasil merupakan pendekatan secara tidak langsung, namun sangat bermanfaat untuk mengukur mutu pelayanan di puskesmas, rumah sakit, atau institusi pelayanan kesehatan lainnya.

Logika yang dipakai adalah jika masukan telah tersedia sesuai rencana, maka proses akan bisa terlaksana. Apabila proses dilaksanakan sesuai yan direncanakan berdasarkan standar yang ada, maka hasil akan tercapai dengan baik.

Dari uraian tersebut, mudah dipahami bahwa terselenggaranya program menjaga mutu pelayanan kesehatan mempunyai peranan yang besar dalam melindungi penyelenggara pelayanan kesehatan dan kemungkinan timbulnya gugatan hukum, karena memang pelayanan kesehatang yang diselenggarakan telah terjamin mutunya.

Adapun Dokumentasi Kegiatan Pengabdian Kepada Masyarakat yang dilaksanakan secara Daring melalui ruang Zoom adalah sebagai berikut:

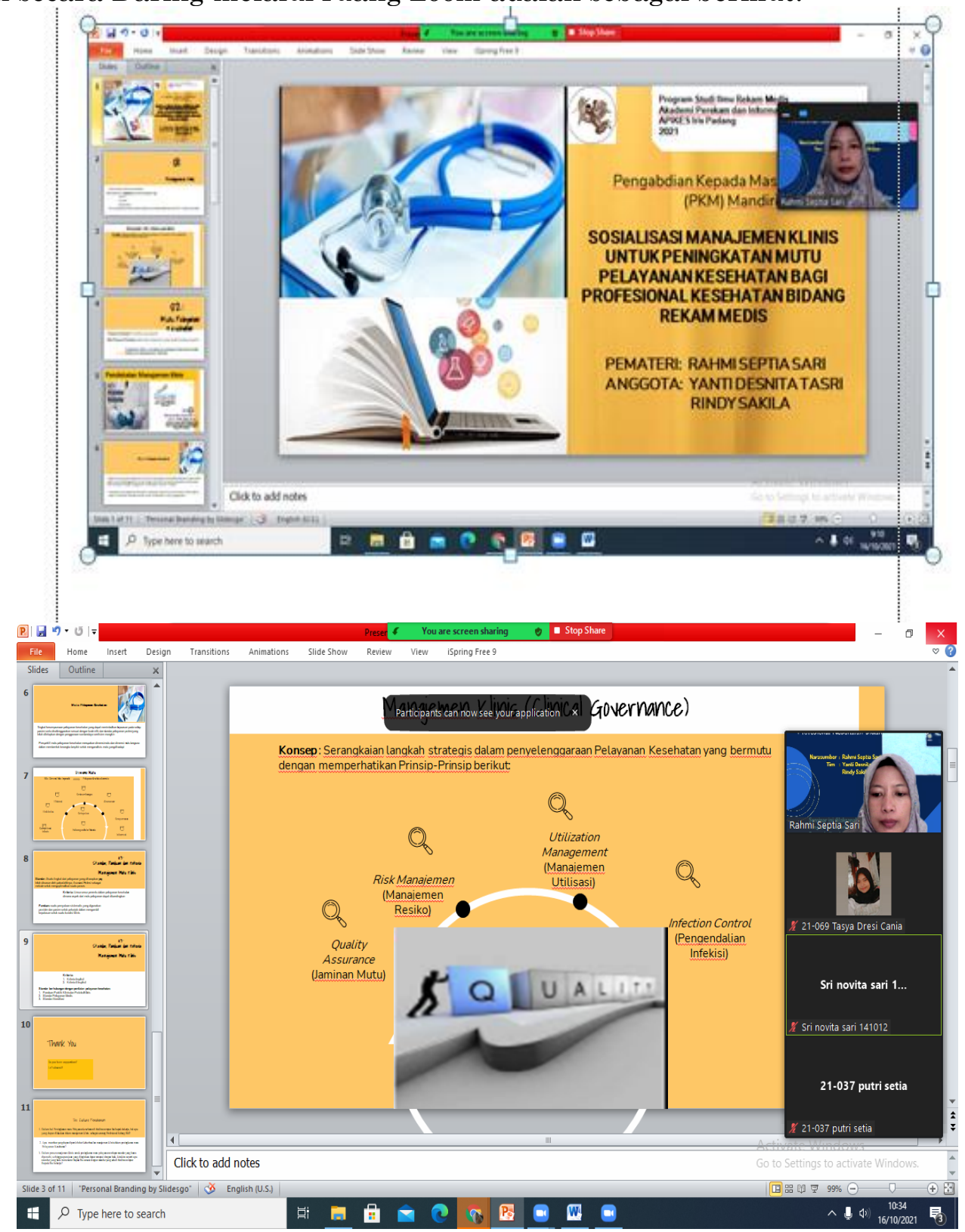

Gambar 1. Presentasi Materi PKM 


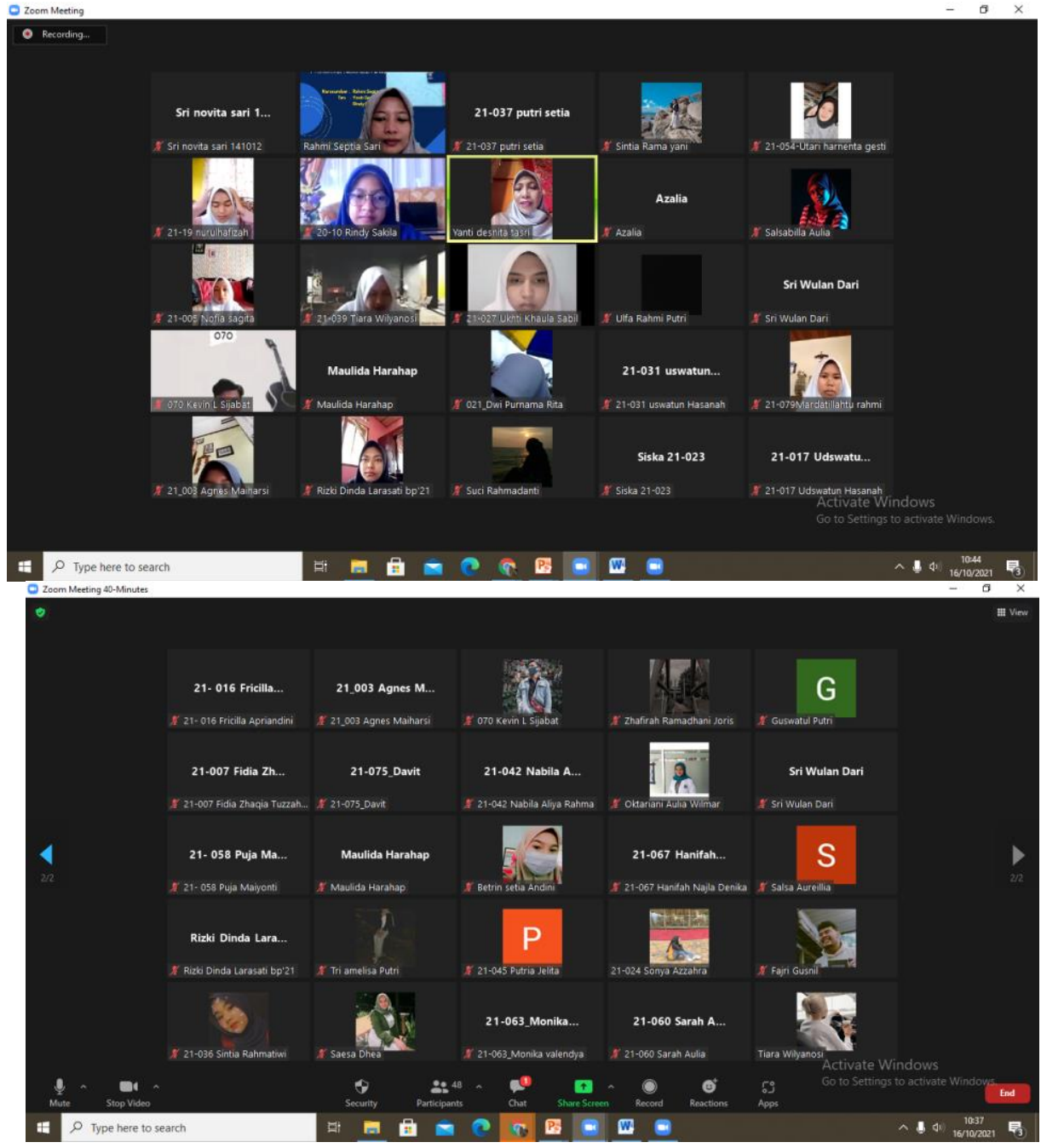

Gambar 2. Peserta PKM

\section{KESIMPULAN}

Dari sosialisasi yang dilakukan dapat dilihat bahwa Mutu pelayanan kesehatan merupakan derajat kesempurnaan pelayanan kesehatan yang sesuai dengan standar profesi dan pelayanan dengan menggunakan potensi sumber daya yang tersedia secara wajar, efisien dan efektif serta diberikan secara aman dan memuaskan norma, etika, hukum, dan sosial budaya dengan memperhatikan keterbatasan dan kemampuan pemerintah dan masyarakat. Terdapat beberapa perspektif mengenai mutu pelayanan kesehatan diantara menurut konsumen layanan kesehatan sebagai suatu layanan kesehatan yang dapat memenuhi kebutuhan masyarakat, menurut provider layanan kesehatan yang bermutu yaitu tersedianya peralatan, prosedur kerja, kebebasan profesi dalam melakukan layanan kesehatan, menurut penyandang dana layanan kesehatan sebagai suatu layanan kesehatan yang efektif dan efisien, menurut pemilik sarana layanan kesehatan bahwa layanan kesehatan yang bermutu dapat menghasilkan pendapatan yang mampu menutupi biaya operasional tetapi terjangkau oleh masyarakat sedangkan menurut administrator layanan kesehatan dapat menyediakan kebutuhan dan harapan pasien serta pemberi layanan kesehatan. Standar mutu pelayanan kesehatan terbagi atas standar persyaratan minimal yaitu menunjuk kepada keadaan minimal yang harus dipenuhi untuk dapat menjamin terselenggaranya pelayanan kesehatan bermutu dan standar penampilan minimal yaitu menunjuk kepada penampilan pelayanan kesehatan yang masih dapat diterima. 
ABDINE: Jurnal Pengabdian Kepada Masyarakat Vol.1, No.2, Desember 2021, Hal. 147-158 p-ISSN 2798-2882, e-ISSN 2798-2890

Pengukuran mutu pelayanan kesehatan terdapat beberapa langkah-langkah yaitu pembentukan kelompok jaminan mutu pelayanan kesehatan, kemudian menyusun standar pelayanan kesehatan setelah itu memilih tehnik yang akan digunakan dalam pengukuran mutu kemudian melakukan pengukuran mutu dengan cara membandingkan standar pelayanan kesehatan dengan kenyataan yang tercapai. Manfaat dari program penjaminan mutu adalah dapat meningkatkan efektifitas pelayanan kesehatan, dapat meningkatkan efisiensi pelayanan kesehatan, dapat meningkatkan penerimaan masyarakat terhadap pelayanan kesehatan, serta dapat melindungi penyelenggara pelayanan kesehatan dan kemungkinan timbulnya gugatan hukum.

Adapun saran yang diberikan yaitu agar mutu pelayanan kesehatan di Indonesia harus lebih ditingkatkan salah satunya dengan meningkatkan disiplin kepada karyawan yang sesuai dengan aturan yang berlaku sehingga dapat menumbuhkan kehandalan dalam memberikan pelayanan kesehatan sehingga ada kepuasan tersendiri bagi konsumen dan akhirnya meningkatkan mutu pelayanan kesehatan baik di rumah sakit maupun di puskesmas dan mencapai masyarakat yang sehat dan terbebas dari berbagai macam penyakit.

\section{DAFTAR PUSTAKA}

A A Gde, M. (2013). Manajemen Pelayanan Mutu Kesehatan. Jakarta: EGC.

Azwar, A. (2013). Menjaga Mutu Pelayanan Kesehatan. Jakarta: Pustaka Sinar harapan.

Bustami. (2016). Penjaminan Mutu Pelayanan Kesehatan \& Aksebilitasnya. Jakarta: Erlangga.

D, W. (2012). Manajemen Mutu Pelayanan Kesehatan, Teori, Strategi dan Aplikasi. Surabaya: Airlangga University Press.

Elisa Hafida, Febrina Sari, Desyanti D, S.N., 2020. DATA MINING PEMBENTUKAN POLA PENGGUNAAN ALAT KONTRASEPSI. , 4(2), pp.186-191.

Elisabeth, \& Elisabeth, S. E. (2015). Mutu Pelayanan Kesehatan dan Kebidanan. Yogyakarta: Pustaka Baru Press.

Herlambang, S. (2016). Manajemen Pelayanan Kesehatan Rumah Sakit. Yogyakarta: Gosyen, Publishing.

Prastiwi, E. N. (2010). Analisis Mutu Pelayanan Intensive Care Unit (ICU) melalui audit kematian di RSUD Kota Bekasi tahun 2009. Jakarta: Universitas Indonesia.

RI, P. (2019). Standar Teknis Pelayanan Dasar Pada Standar Pelayanan Minimal Bidang Kesehatan. Jakarta: Permenkes RI.

Sabarguna, B. S. (2014). Quality Assurance Pelayanan Rumah Sakit Yogyakarta. Yogyakarta: Konsorsium Rs Islam Jateng_DIY.

Spath, P. (2014). Introduction to healthcare Quality Management. Washington DC: Patrice Spath Health Administration Press, Chicago Illinois AUPHA Press. 